\title{
The Current Situation and Development of Huangmei Opera Tourism Resources in Huanggang Area
}

\author{
Ping $\operatorname{Liu}^{1, *}$ \\ ${ }^{1}$ Conservatory of Music, Huanggang Normal University, Huanggang, Hubei, China \\ *Corresponding author. Email: liupingzhongguo@163.com
}

\begin{abstract}
Huanggang City, Hubei Province is located in the southeast of Hubei Province. It has a history of more than 2,000 years of construction and is rich in tourism and human resources. Huangmei opera was born in Huangmei County, Huanggang City, and is called the five major Chinese operas together with Peking opera, Yue opera, Ping opera, and He'nan opera. Based on the analysis of Huangmei opera culture and the existing resources of Huanggang tourism, this article strives to create a distinctive Huanggang local Huangmei opera tourism and cultural industry through the artistic charm of Huangmei opera and combining the existing tourism resources in Huanggang area.
\end{abstract}

Keywords: Huangmei opera, Tourism resources, Current situation, Development.

\section{INTRODUCTION}

Huanggang City is located in the east of Hubei Province, the southern foot of Dabie Mountain, and the north bank of the middle reaches of the Yangtze River. Its history and culture have a long history. It gave birth to the forth ancestor Daoxin, the fifth ancestor Hongren, and the sixth ancestor Huineng of Chinese Buddhism and Zen, the inventor of movable type printing $\mathrm{Bi}$ Sheng in the Song Dynasty, the medical saint Li Shizhen of the Ming Dynasty, the modern geological science giant $\mathrm{Li}$ Siguang, patriotic poet and scholar Wen Yiduo, the master of studies of Chinese ancient civilization Huang Kan, philosopher Xiong Shili, literary critic $\mathrm{Hu}$ Feng, and a large number of scientific and cultural masters. Huangmei opera was born in Huangmei County, Huanggang City, Hubei Province. It is also called "Tea-leaf Picking Opera, Huangmei Opera, Flower Drum Opera, Tea Basket Opera, and Ergao Tune", etc. Its singing is simple

*Fund: This paper was funded by the scientific research project of Huangmei Opera Research Center, the key research base of humanities and social sciences in ordinary universities in Hubei Province, project batch number: 2015025303; Funded by the High-level Training Project of Huanggang Normal University, project batch number: 201708903. The phased results of the "Drama and Film Studies" project of Hubei Province's "Twelfth Five-Year" key discipline. and smooth, with beautiful melody, bright colors, rich expressiveness and fresh native flavor. With the continuous development of China's tourism industry, the demand of the tourism market is showing a trend of diversification and individualization, and the position and role of culture in tourism is becoming more and more obvious [1]. It is an important strategy for the development of tourism culture in the new era by building a tourism and cultural industry of Huangmei Opera in Huanggang, Hubei, using and developing unique tourism resources of Huangmei Opera, and developing high-level tourism cultural connotations [2].

\section{AN OVERVIEW OF TOURISM RESOURCES IN HUANGGANG AREA}

Huanggang is rich in tourism resources, with distinctive red culture, celebrity culture, Dongpo culture, Huangmei opera culture, and Zen culture. Huanggang has a profound cultural heritage. The red culture there is brilliant. Dongpo culture in Huanggang is well-known in China and foreign countries. There is a profound accumulation of opera culture. Meanwhile in Huanggang, Zen culture is famous all over the world, health culture 
attracts worldwide attention, and celebrity culture is well-known. The city has 5768 cultural relics, more than 1,600 historical and cultural celebrities, 13 national key cultural relics protection units, 8 national intangible cultural heritage, 4 Chinese folk culture and art townships, and 6 traditional Chinese villages. There are also colorful folk cultural heritages such as Huangmei opera, Huangmei fower picking, Hong'an embroidery, Huangmei Zen patriarch legend, Li Shizhen legend, Hubei drum, Donglu flower drum opera, Yuejiaquan and so on.

In 2007, the Huanggang Municipal Party Committee and Municipal Government issued the "Decision on Accelerating the Development of Tourism Economy", which put forward the goal of Huanggang to create a "Chinese Tourism City". Under the leadership of the Municipal Party Committee and the Municipal Government, a tourism system featuring red cultural tours, green ecological tours and patina Zen tours in Huanggang City has been established, and a number of highquality tourism routes around the characteristic tourism system have been created. "Amorous Dabie Mountains and a romantic view of Huanggang." During the "Twelfth Five-Year Plan" period, the latest statistics from the Huanggang Tourism Department show that the number of tourists in Huanggang has exceeded 76 million in the past five years, achieving a comprehensive tourism income of 43 billion yuan, maintaining a growth rate of more than $20 \%$ for 7 consecutive years, and having more than 14 national $4 \mathrm{~A}$ scenic spots and 17 drifting scenic spots, and one of the country's 12 major red tourism base... These leaping figures and these fruitful results are the result of Huanggang City's acceleration of cultivating tourism as an important pillar industry of Huanggang. These five years have also been the best and fastest "Golden Five Years" in the history of Huanggang tourism development.

\section{THE CURRENT SITUATION OF HUANGMEI OPERA TOURISM RESOURCES}

After years of development in Huanggang, Huangmei opera has gradually formed a unique expression style and artistic characteristics. It also created a lot of repertoires representing the characteristics of the folk customs of Huanggang, such as "Li Siguang", "Su Dongpo" and so on. As a special cultural resource, it contains relatively rich tourism development value:
- Huangmei opera performance art has its unique performance art form after refining the rural life.

- The content of Huangmei opera performance is close to the lives of working people, expressing the thoughts and feelings of ordinary people, and has distinctive characteristics of the times and prominent mass characteristics.

- The language of Huangmei opera is based on the local dialect of Huangmei, which is rich in content, flexible, and expressive.

- The music of Huangmei opera unifies its own characteristics and popular appreciation. It is popular, simple, plastic and unique in aesthetics, which gives the opera a strong sense of music and audience affinity.

However, there are still some problems in Huangmei opera tourism in Huanggang area:

- First, the development of Huangmei opera tourism in Huanggang area is relatively low.

The tourism infrastructure and supporting facilities of Huangmei opera in Huanggang area are not sound enough, and its tourism development is only on the surface. The specific manifestation are: The in-depth development of Huangmei opera tourism products and the standardized construction and management of the tourism market are still in the groping stage; The artistic characteristics and cultural level of Huangmei opera should be further improved to meet the increasingly perfect tourism demand; The tourism potential of Huangmei opera has not been tapped enough, and it is merely a simple display without forming a supporting industry.

- Second, there is a lack of brand image of Huangmei opera tourism in Huanggang area.

Brand characteristics are the driving force and selling point to attract tourists. The Huangmei Opera tourism in Huanggang area lacks the packaging of the tourism resources, does not form a Huangmei opera tourism project with local characteristics or high-quality goods, and lacks the corresponding brand effect of Huangmei opera tourism products, which makes tourists not highly aware of Huangmei opera tourism. 
- Third, the promotion of Huangmei Opera tourism in Huanggang area is insufficient.

Huangmei opera tourism is a relatively new model. To attract the attention of tourist groups, there must be sufficient publicity and tourism products. At present, the Huanggang area has insufficient publicity on Huangmei opera tourism and lacks public media and other publicity methods. Although the Huangmei opera is circulated in the local area, there is no better way to spread it.

- Forth, the professional talents in Huangmei opera tourism in Huanggang area are scarce.

The development of tourism resources of Huangmei opera must have supporting service personnel and a team of high-quality professionals, including the inheritors of Huangmei opera, experts in Huangmei opera theory research, managers, operators, tour guides, etc. of Huangmei opera tourism. These talents need to have some knowledge about opera and tourism, so that in the development of Huangmei opera tourism, they have enough professional knowledge to deal with problems that arise.

\section{DEVELOPMENT AND SUGGESTIONS ON HUANGMEI OPERA TOURISM IN HUANGGANG AREA}

\subsection{The Development History of Huangmei Opera Tourism Resources in Huanggang Area}

The origin of Huangmei opera can be traced back to the Tang Dynasty. According to historical records, as early as the Tang Dynasty, Huangmei Tea-leaf Picking Opera had been very popular. After the development of Song Dynasty folk songs and Yuan Dynasty Zaju, the embryonic form of Huangmei folk opera was gradually formed. In the Ming and Qing Dynasties, Huangmei County was more prosperous in drama. From the late Qianlong period of the Qing Dynasty to the Xinhai Revolution, it was the early stage of the development of Huangmei opera. Huangmei opera was listed in the first batch of national intangible cultural heritage lists in 2006. Huangmei opera has experienced four historical stages from its origin to development: one-man opera, three playlets, three hits and seven singing, and orchestral accompaniment. The first three stages were all completed in Huangmei, Hubei, which provided sufficient preconditions for the final formation of Huangmei opera species. These traditional resources are not only an important cornerstone of the artistic development of Huangmei opera, but also a valuable asset for the cultural industry of Huangmei opera to grow bigger and stronger. Combining the historical and developmental characteristics of Huangmei opera, exploring the relationship between tea-leaf picking songs and Huangmei opera, and striving to create repertoires and works with local characteristics and culture of Huangmei opera, the Huangmei opera and Huanggang tourism resources are closely integrated and become the brand power of Huanggang tourism.

After long-term development and training, Huangmei opera has gathered a large number of talents. From script creation to stage performance, from academic research to market operation, from popularization to the promotion in China and foreign countries, there is a dedicated team of talents for deep cultivation. Huanggang Normal University and Huanggang Art School are to cultivate professional talents in Huangmei opera in Huanggang. Among them, Huanggang Normal University has set up the Huangmei Opera Art Academy, and hired famous Huangmei Opera performing artists and the winner of the "Plum Blossom Award" for Chinese theater as a part-time professor; Acting major (Huangmei Opera performance direction) began to recruit students in 2017; The school's Huangmei Opera Art Research Center is the "Key Research Base of Humanities and Social Sciences in Universities in Hubei Province". The work of the center "Research on Hubei Huangmei Opera (1984-2011)" was reviewed by the Hubei Provincial Federation of Literary and Art Circles and Hubei Provincial Association of Literary Theorists It was the Excellence Award of the 8th Hubei Literature and Art Review Award, and the research result "On the Three Stages of the Development of Huangmei Opera Musical Accompaniment" won the third prize of the 9th Hubei Literature and Art Review Award. Researchers have published many academic papers on the research direction of Huangmei opera's art in core journals such as "Chinese Drama", "Opera Research", "Literary Controversy". With the increasing development of the market economy, the Huangmei opera industry chain has taken shape. The large-scale Huangmei oera stage plays "Li Siguang" and "Su Dongpo" arranged by the Huangmei Theater of Hubei Province have won 
praise from the audience for their beautiful stage modeling, vivid character creation and full storyline. Huanggang Huangmei Opera Hall is under preparation...The development of the Huangmei opera cultural industry in Huanggang area has shown a good development trend and achieved staged development results, which provides good support for the further development of Huangmei opera tourism.

The supporting cultural system and industrial construction are the main factors affecting the development of tourism, and perfecting the supporting system is the key to the development of local tourism. The tourism industry is a comprehensive industry that must be fully developed and integrated organically [3]. Therefore, the construction of the tourism industry must shift from the previous construction of scenic spots and publicity and promotion to the construction of the cultural industry system. For the tourism industry, it is a must to establish and improve systems for job training, qualification certification, skill assessment, job assessment and level certification for tourism practitioners. Huangmei opera has achieved some success in digging local traditional cultural resources, creating local characteristics, and meeting the cultural needs of local people, but it has done little to develop industrialization of going global. It is necessary to take music and plot as the soul, unify the form and content, and reflect the comprehensive beauty of Huangmei opera. It is also necessary to intensify tourism promotion efforts, launch tourism advertising videos, and increase the tourism visibility of Huangmei opera in Huanggang area. Meanwhile, it is of great significance to promote Huangmei opera to expand the influence of Huanggang tourism and make it a business card for Huanggang tourism to go global.

\subsection{Suggestions on the Development Model of Huangmei Opera Tourism Resources in Huanggang Area}

\subsubsection{Park-touring Model}

Huangmei Opera Tourist Park in Huanggang area needs to be constructed. The park-touring model conforms to the cultural atmosphere of Huanggang area and the living habits of the people in Huanggang, and improves the experience and enthusiasm of tourists. There needs to be a theater and experience area in the park to gather the art of Huangmei opera to reflect the culture and art of
Huangmei opera from multiple angles. Showing the leisure, participation and entertainment characteristics of Huangmei opera, Huangmei opera tourism products should also reflect participation and experience in all aspects, allowing tourists to participate in the role-playing of opera, wearing costumes and makeup, and learning to sing Huangmei opera. Visitors can participate in it to truly feel the cultural charm of Huangmei opera, cultivate the cognitive level of Huangmei opera, enhance the influence of Huangmei opera, and enjoy the fun of Huangmei opera park-touring.

\subsubsection{Festival Model}

Festival tourism is currently an important means of attracting tourists, and it is a form of tourism held in various places with unique opera culture as its main competitiveness. In the Huanggang area, according to the development of Huangmei opera, the following types of festivals can be planned: One is to plan a comprehensive Huangmei opera festival in the Huanggang area. Various opera troupes of Huanggang County can jointly hold opera festivals. The festival activities mainly focus on Huangmei opera, which can include repertoire performance, public review and selection of excellent operas, etc., to promote and publicize Huangmei opera on a large scale and expand market influence. The second is the Huangmei opera festival for specific appreciation groups. In order to strengthen the pertinence of Huangmei opera festival activities, corresponding Huangmei opera festival activities can be held according to the characteristics of the appreciation group. For example, in the Huangmei opera festival for the rural market, the stage is built at the grassroots level to enrich the cultural life of the farmers' appreciation group and promote the development of the folk Huangmei opera troupes. The Huangmei Opera Art Festival for college, middle and elementary school students can learn from the national student-type opera festival model, which is led by the Education Bureau and universities. The third is to select some professionals from Huangmei opera to participate in various opera festivals in China and foreign countries. In the festival activities, the culture of Huangmei opera can be promoted and the influence of Huangmei opera can be further expanded in China and foreign countries.

\subsubsection{Gallery Model}

The gallery model refers to the combination of the cultural connotation, development context, 
historical evolution and artistic characteristics of Huangmei opera and other related audio-visual materials and books in various forms and concentrated display in the Opera Museum. The Opera Museum can comprehensively display the emergence, development, evolution, and innovation of Huangmei opera, which can be divided into comprehensive and specific aspects. The comprehensive opera museum can show the characteristics of multiple types of opera, while the special opera museum focuses on the characteristics of one type of opera. In view of the situation in Huanggang area, a special Huangmei Opera Museum can be constructed. The museum can be built next to the Huangmei Theater in Hubei Province. The exhibition hall displays various related documents, fine cultural relics, costume props worn by famous performers, and manuscripts created by playwrights.

\section{CONCLUSION}

With the continuous progress of human society and the continuous improvement of people's living standards, the demand for culture and tourism continues to increase, and cultural tourism industry in China is also gradually rising, developing and growing [4]. Generally speaking, China's cultural tourism industry has shown a trend of vigorous development and has made remarkable achievements. The combination of Huangmei opera and local tourism not only opens up a new path for the inheritance and development of Huangmei opera in contemporary opera, but also plays an incalculable role in the development of local tourism of Huangmei opera. It is one of the effective ways for the development of Huangmei opera today [5].

However, there are also some contradictions and problems in the development of cultural tourism industry, such as:

- The integration of culture and tourism industry

The integration of culture and tourism industry is an important driving force for the structure of the tourism industry. It is necessary to integrate resources, functions, products, markets and other aspects to achieve the improvement and optimization of the internal structure of the cultural tourism industry.

- The market optimization of culture and tourism industry
The marketization process is an important role in the structure of cultural tourism industry. On the one hand, it is necessary to improve the tourism agency and legal system; on the other hand, it is also necessary to clarify the synergy of the market mechanism in the process of integration of culture and tourism industry.

- The government regulation of culture and tourism industry

Government regulations have a promoting effect on the cultural tourism industry. Government regulation is a policy tool for optimizing the structure of the cultural tourism industry. It promotes the uniform development and integration of all aspects of culture and tourism, makes better use of the government's guidance, regulation and service functions, and improves the overall effect of the cultural tourism industry [6].

In summary, the tourism resources of Huanggang area are unique, and the tourism industry has great potential and space for development. As the origin of Huangmei opera, Huanggang area has the unique tourism resource of Huangmei opera. If Huangmei opera and tourism resources of Huanggang area are combined organically, they can form a synergy, promote each other, and improve together, which can promote the rapid development of tourism in Huanggang area and can promote the prosperity of Huangmei opera at the same time.

\section{AUTHORS' CONTRIBUTIONS} Liu.

This paper is independently completed by Ping

\section{REFERENCES}

[1] Li Wei, Probe into the Development Path of Shanxi Cultural Tourism Industry Resources Integration [J]. Tourism Today, 2021.19(03). (in Chinese)

[2] Tong Meng, A Study on the Promotion of Chengde Folk Music Industrialization by the Travelling in the Horizon of Cultural Creativity [J]. JinGu Creative Literature, 2021. (03). (in Chinese)

[3] Chang Xuelian, Liu Jia, Integration of Culture and Tourism:Development of Drama Tourism in Northern Shanxi [J]. Journal of North University of China: Social Science Edition, 2021. 37(01). (in Chinese) 
[4] Hou Kena, On the Development of Ecotourism in Local Opera [J]. Popular Songs, 2014. (04). (in Chinese)

[5] Yang Xiaoqiao, Reflections on the Realistic Significance of the Construction of Huangmei Opera Museum [J]. Art of Huangmei Opera, 2011. (01). (in Chinese)

[6] Xiao Mudan. Some Thoughts on the Brand Construction and Tourism Development of "The Hometown of Chinese Folk Arts Hubei Tianmen" [J]. Drama Home, 2015. (19). (in Chinese) 